\title{
Features of measures to prevent fraud committed by women: The experience of Ukraine, the European Union countries and the United States
}

Características de las medidas de prevención del fraude cometido por mujeres: la experiencia de Ucrania, los países de la Unión Europea y los Estados Unidos

Características das medidas para evitar fraudes cometidas por mulheres: A experiência da Ucrânia, dos países da União Europeia e dos Estados Unidos

\author{
Viktoria Babanina ${ }^{1}$ \\ Oleksandr Mykytchyk ${ }^{2}$ \\ Inna Vartyletska ${ }^{3}$ \\ Valentyn Bortnyk ${ }^{4}$
}

Received: April $15^{\text {th }}, 2021$

Accepted: May $28^{\text {th }}, 2021$

Published: July $6^{\text {th }}, 2021$

How to cite this article:

Viktoria Babanina, Oleksandr Mykytchyk, Inna Vartyletska \& Valentyn Bortnyk. Features of measures to prevent fraud committed by women: The experience of Ukraine, the European Union countries and the United States.

DIXI, vol. 23, $n^{\circ}$. 2, julio-diciembre 2021, 1-23.

DOI: https://doi.org/10.16925/2357-5891.2021.02.02

Research article. https://doi.org/10.16925/2357-5891.2021.02.02

1 Ph.D. Professor of Criminal Law Department, National Academy of Internal Affairs, Kyiv, Ukraine.

E-mail:v774910@gmail.com

ORCID: https://orcid.org/0000-0003-4173-488X

2 Ph.D. Professor of Criminal Law Department, National Academy of Internal Affairs, Kyiv, Ukraine.

E-mail: mikitcik@bigmir.net

ORCID: https://orcid.org/0000-0002-4973-2670

3 Ph.D. Professor of Criminal Law Department, National Academy of Internal Affairs, Kyiv, Ukraine.

E-mail: vartuleska@meta.ua ORCID: https://orcid.org/0000-0002-3447-0567

4 Ph.D. Deputy Head of the Department of Administrative, Financial and Banking Law, Interregional Academy of Personnel Management, Kyiv, Ukraine.

E-mail: fin486@ukr.net 
2 Features of measures to prevent fraud committed by women: The experience of Ukraine, the European Union countries and the United States

\section{Abstract}

The article analyzes and studies approaches to the prevention of female fraud, including the experience of the EU countries and the United States in programs and methods of prevention, in order to identify the best ways to combat fraud committed by women, and also examines theoretical approaches to the measures to prevent crimes committed by women, in particular, female fraud. Peculiarities of the legal regulation of the prevention of female fraud in Ukraine have been studied. The conclusion was made about the insufficiency of normative acts aimed at combating female fraud in Ukraine. In addition, the investigation revealed that measures taken in Ukraine to prevent female fraud were poor and insufficient. Based on this analysis, proposals to improve approaches to the prevention of female crime, in particular, female fraud, have been developed. The conclusion made was that preventive work among the population as well as creation of special programs to work with women would be relevant.

Keywords: Combating crime, female crime, fraud, prevention, victimology, women's rights.

\section{Resumen}

El artículo analiza y estudia los enfoques de la prevención del fraude femenino, incluyendo la experiencia de los países de la Unión Europea y de Estados Unidos en programas y métodos de prevención, con el fin de identificar las mejores formas de combatir el fraude cometido por mujeres, y también examina los enfoques teóricos de las medidas de prevención de los delitos cometidos por mujeres, en particular, el fraude femenino. Se han estudiado las peculiaridades de la regulación legal de la prevención del fraude femenino en Ucrania. Se llegó a la conclusión de la insuficiencia de los actos normativos destinados a combatir el fraude femenino en Ucrania. Además, la investigación reveló que las medidas adoptadas en Ucrania para prevenir el fraude femenino eran pobres e insuficientes. Sobre la base de este análisis, se han elaborado propuestas para mejorar los enfoques de la prevención de la delincuencia femenina, en particular, del fraude femenino. La conclusión a la que se llegó fue que sería pertinente el trabajo preventivo entre la población, así como la creación de programas especiales para trabajar con las mujeres.

Palabras clave: lucha contra la delincuencia, delincuencia femenina, fraude, prevención, victimología, derechos de la mujer.

\section{Resumo}

O artigo analisa e estuda abordagens para a prevenção da fraude feminina, incluindo a experiência dos países da União Europeia e dos Estados Unidos em programas e métodos de prevenção, a fim de identificar as melhores maneiras de combater a fraude cometida por mulheres, e também examina abordagens teóricas das medidas para prevenir crimes cometidos por mulheres, em particular, a fraude feminina. Foram estudadas as peculiaridades da regulamentação legal da prevenção de fraudes femininas na Ucrânia. A conclusão foi feita sobre a insuficiência de atos normativos destinados a combater as fraudes femininas na Ucrânia. Além disso, a investigação revelou que as medidas tomadas na Ucrânia para prevenir a fraude feminina eram pobres e insuficientes. Com base nesta análise, foram desenvolvidas propostas para melhorar as abordagens para a prevenção da criminalidade feminina, em particular, a fraude feminina. A conclusão feita foi que o trabalho preventivo entre a população, bem como a criação de programas especiais para trabalhar com as mulheres, seria relevante.

Palavras-chave: Combate ao crime, crime feminino, fraude, prevenção, vitimologia, direitos da mulher. 


\section{INTRODUCTION}

In recent years, women's crime has become one of the most pressing socio-legal problems of modern society. This extremely socially dangerous phenomenon has a negative impact on the institution of the family and the spiritual and moral upbringing of children, on the development and formation of value orientations of future generations, and in general serves as a kind of indicator of public health. The increased social danger of women's crime is due to the growth of its level of professionalism and organization (established facts when organized criminal groups are led by women).

Among the mercenary crimes committed by women, one of the most common and prone to rapid growth is fraud. Areas where a woman commits crimes primarily related to free access to property (e.g. trade, catering, and accounting) or to corrupt schemes (medicine, education, etc.). Most women work in such a criminalized field as trafficking, so it is no coincidence that they are more prevalent in fraud.

Fraud committed by women can be domestic, professional and financial. The most common methods of fraud are: Borrowing money and valuables without the intention of returning them to the owner; pseudo-mediation in bribing officials; falsification frauds; fraud in real estate transactions or car sales; pretending assistance in purchasing goods; deception about objects, things, their quality and quantity. Most often, such acts are committed in markets, near shops, warehouses, bases, stations. Fraudsters operate in a group with pre-assigned roles. They react immediately to changes in the situation and, in case of danger of exposure, provide possible options for disappearance. New types of female fraud related to the provision of intimate services are becoming more active.

Prevention of fraud, especially its professional forms, in particular, committed by women in modern conditions is quite difficult, but it is possible to reduce it at least to a certain minimum level, taking into account modern economic, social and other conditions.

\section{GENERAL CHARACTERISTICS OF FEMALE FRAUD PREVENTION IN UKRAINE}

Reducing the prevalence of fraud and reducing its severity cannot be achieved by criminal punishment alone, as such measures cannot eliminate the social causes and conditions of fraud. Combating it can only be effective using an integrated approach, i.e. not only detection, cessation and investigation, but also prevention. 
4 Features of measures to prevent fraud committed by women: The experience of Ukraine, the European Union countries and the United States

Prevention of female crime, namely fraud committed by them, in its social significance goes far beyond the problem of combating crime. Crime prevention consists of hierarchically related tasks. The first of them is a preventive effect on the dynamics, structure, causes of crime in general (general social prevention). The second one is prevention of types and forms of criminal behavior, prevention of crimes in certain spheres of public life, prevention of crimes committed by certain social groups of persons, etc. (special criminological prevention). The third task is to prevent crimes by individuals (individual prevention). ${ }^{1}$

Victimological prevention occupies a special place. An important place in the system of measures of victimological prevention of fraud should be informational and educational work with the population, which will be carried out not only to guide the behavior of citizens in the legal direction, but also to promote morality and to clarify the content of current legislation: The procedure for concluding civil agreements, informing about their typical conditions, responsibility for their violation, about ways to ensure the fulfillment of obligations².

Crime prevention should be understood as a set of various activities and measures in the state aimed at improving social relations, in order to eliminate negative phenomena and processes that give rise to or contribute to crime, as well as to prevent crime at various stages of criminal behavior. ${ }^{3}$ According to I. Meditskyi, the system of general prevention measures includes:

- Measures to identify and study the causes of crime as a phenomenon;

- Measures to prevent certain types of crime;

- Measures to identify and eliminate the causes of certain groups and types of crimes, the conditions that contributed to them;

- Measures to eliminate objective circumstances that make it possible to commit crimes or facilitate the achievement of a criminal result. ${ }^{4}$

Given the above, it is necessary to agree with the position of scholars, who believe that to ensure the effectiveness of crime prevention measures among women, prevention activities should be considered as:

1 Djuja Olexandr et al. PREVEnTION OF CRIMES. Atica. (2011).

2 K. L. Popov. Victim of fraud: Victimological Research. Kyiv. (2007). Pg. 17.

3 Golina Volodymyr et al. CRIMINOLOgY: GENERAL AND SPECIAL PARTS. Kharkiv Law Institute. (2009). Pg. 53.

4 I. B. Meditsky. PREVEntIon of CRIME. Viktor Dyakiv. (2008). Pg. 27. 
- One of the means of social regulation of public relations in order to eliminate the causes of crime;

- Interaction of measures of economic and social, educational and pedagogical, organizational and legal nature;

- A combination of different levels of crime prevention. Crime prevention consists of hierarchically related tasks. ${ }^{5}$

Thus, we must agree with the statement that general social prevention is not only the subject of criminological science, because general social activities are carried out outside the fight against crime and are aimed at fulfilling common objectives: Stabilizing the economy, social development, improving moral and psychological atmosphere in society, etc. At the same time, mistakes in the development and implementation of economic, social, cultural and spiritual policy of the state can contribute to the outbreak of criminal acts in society or in its individual regions. That is why criminologists monitor the processes of development and implementation of state policy in all spheres of society. ${ }^{6}$

The general type of crime prevention (general prevention) covers the activities of the state, society and their institutions, and it is aimed at resolving conflicts in the field of economy, social life, moral sphere, etc. This activity is carried out by various bodies of state power and administration, public formations for which the function of crime prevention is not basic or professional. The preventive effect is achieved through effective socio-economic policy in general. ${ }^{7}$ General prevention of crimes can be defined as detection and elimination of objective external causes that give rise to crimes and conditions that contribute to their commission, as well as of circumstances that facilitate the achievement of a criminal result. ${ }^{8}$

Therefore, it is appropriate, in our opinion, to support the position on understanding the measures of general social (state) nature as a set of effective measures of socio-economic, legal, ideological, organizational and managerial, cultural and educational content aimed at further development and improvement of public relations and at the elimination or neutralization of the determinants of crime. ${ }^{9}$

5 Djuja Olexandr et al., supra, note 1.

6 V. Kovalenko. General Social Conditions for Crime Prevention in the Economic Sphere. LAW OF UKRAINE 8. 2004. Pg. 12-18.

7 I. B. Meditsky, supra, note 4. Pg. 20.

8 E. I. Kairzhanov. THE CONCEPT, STRUCTURE AND TYPES OF CRIME PREVENTION. HSh. MIA USSR. (1986). Pg. 52.

9 O. M. Litvinov. General Social Vector in the Mechanism of Crime Prevention and Factors that Determine it. BULLETIN OF KHARKIV NATIONAL UNIVERSITY OF INTERNAL AFFAIRS 41. 2008. Pg. 111-117. 
It should be noted that the general social prevention of crime is the first fundamental direction to improve social relations in socio-economic, political, ideological, legal, moral and psychological areas, among others. Therefore, this level of crime prevention involves the development of such a socio-psychological mechanism in society, which would allow to block destructive behavior and eliminate the causes and conditions that contribute to it. ${ }^{10}$ General social prevention of women's crime, namely fraud, is to implement a set of measures to improve social relations in the administrative-political, economic and socio-economic spheres of life of our people. The purpose of these measures should be to address the problems of women in our society. First of all, women must be guaranteed real equality of rights with men. It is well known that in the case of any reductions in production, women are the first to be laid off; women are also paid less than men; when hiring, preference is also given to men. ${ }^{11}$

Taking into account various aspects (political, social, economic, ideological, etc.), criminologists have developed a definition of general social crime prevention. It is a system of economic, social, political, ideological, cultural and organizational measures aimed at the state and society to develop the economy, improve the welfare of the people, improve the cultural level, strengthen law and order, and create favorable conditions for work, life and recreation of all citizens. ${ }^{12}$

Measures of general social prevention of women's crime (i.e. social, economic, ideological, cultural and educational) are extremely important for improving the current situation with women's crime. One of the main ways to improve public relations in these areas is the legal regulation of various state and public institutions, individual citizens, which affects the lives of women and, consequently, changes their values, beliefs and habits. ${ }^{13}$

Women's crime is a set of crimes committed by women. This type of crime is not dominant, but it is part of general crime and is determined by the same causes and conditions. However, women's crime has certain features related to both biological and social factors that determine a woman's physiological purpose as a mother and

10 M. G. Kolodyazhny. VIOLENT EXTORTION OF PROPERTY IN UKRAINE: CRIMINOLOGICAL CHARACTERISTICS, DETERMINATION AND PREVEntion. Crossroad. (2010). Pg. 163.

11 Marcela Pilar Aedo Rivera \& Patricia Varela Pino. Reflections about Gender Differences in Girls' Delinquency Behaviors in Chile. ONATI SOCIO-LEgAL SERIES 1. (2020). Pg. 218242. Available at: https://doi.org/10.35295/OSLS.IISL/0000-0000-0000-1164

12 S. I. Minchenko. The Main Directions of General Social Crime Prevention in Ukraine. SCIENTIFIC BULLETIN OF KYIV NATIONAL UNIVERSITY OF INTERNAL AFFAIRS 5. 2009. Pg. 102-110.

13 O. M. Podilchak. motives AND MOtivation of CRIMES COMMITTED BY WOMEN. Ranok Publishing House. (2005). Pg. 16. 
her social status in society. Women's crime, like juvenile delinquency, is an indicator of the moral health of society. Women's crime differs from men's crime in quantitative indicators, the nature of crimes, the role of women in crimes committed with men, and methods and tools of crime.

We agree with the opinion that the central idea of general crime prevention is the idea of influencing the deterministic complex of crime. ${ }^{14}$ After all, in order to prevent crime, it is first of all necessary to neutralize or eliminate its determinants.

\section{THE MAIN DIRECTIONS OF PREVENTION OF FEMALE FRAUD IN UKRAINE}

General social prevention of women's crime includes:

- Improving the legislation and practice of its application in terms of humanity and mercy to women who have committed a crime;

- Strengthening social support for unemployed women (increasing financial assistance, promoting their retraining, creating additional jobs for women);

- Improving living conditions, strengthening the family, enhancing the working conditions of women, so that the workload does not interfere with child care or recreation;

- Education of female, not male type of behavior;

- Organizational and material support for the development of forms of leisure available to most women;

- Carrying out of cultural and educational actions directed on increase of ethical, labor, aesthetic and legal culture, etc. ${ }^{15}$

The basis of all preventive work should address the following issues:

- Providing women with jobs and wages;

- Improving their education and skills;

- Help for families with children;

- Protection of morality, dignity and honor of women;

- Conducting of social and educational activities. ${ }^{16}$

14 A. F. Tokarev. GENERAL WARNING IN THE ACTIVITIES OF LAW ENFORCEMENT AGENCIES. Academy of the Ministry of Internal Affairs of Russia. (1995). Pg. 8.

15 Djuja Olexandr et al., supra, note 1.

16 Djuja Olexandr et al. CRIMINology. Atica. (2009). Pg. 242. 
8 Features of measures to prevent fraud committed by women: The experience of Ukraine, the European Union countries and the United States

Prevention of crime in general and women in particular is carried out by state and non-state bodies, officials and non-officials through coercion, education, protection of the rights and legitimate interests of the individual and society, social and legal assistance to eliminate or neutralize the determinants of crime. ${ }^{17}$

According to some scholars, we can identify the following measures to combat fraud:

1. Improving the social policy of the state, focused on ensuring the fundamental rights and interests of the individual, and based on a gender-sensitive approach in the interests of social welfare of women, families, motherhood and childhood;

2. Development and implementation of broad cultural, educational and spiritual and moral programs aimed at protecting, strengthening and educating among the population a socially positive model of worldview, which affirms the role and importance of women, preservation and strengthening of family principles;

3. Creation and development at the modern level of the system of crime prevention of women. At the same time, along with measures of a general social nature, it is necessary to intensify the fight against women's marginal, pre-criminal behavior;

4. Wide use of scientific recommendations in the field of combating women's crime. The tender approach to this problem should be audible both at the level of rule-making, during the criminological examination of bills, and in the practice of all law enforcement agencies, including at the stage of training its future employees, in the process of their training;

5. Study and application of the experience of international practice in combating women's crime in order to borrow the best, acceptable in the current achievements ${ }^{18}$.

Obviously, it is not possible to completely eradicate crime, but efforts must be made to reduce the growing trend of crime. Prevention of women's crime, as a type of crime, requires special attention, because women are characterized by increased emotionality, sometimes imbalance, and therefore often a stressful situation can lead

17 M. Lototsky. Features of Women's Crime Prevention. UNIVERSITY SCIENTIFIC NOTES: JOURNAL OF IVANO-FRANKIVSK UNIVERSITY OF LAW NAMED AFTER KING DANYLO HALYTSKY 3. 2011. Pg. 466-471.

18 N. A. Chikisheva. WOMEN'S FRAUD: CRIMINOLOGICAL AND VICTIMOLOGICAL CHARACTERISTICS. Vladivostok. (2011). Pg. 183. 
to a woman committing a crime. In our opinion, to gradually reduce the manifestations of such a socially negative phenomenon it is necessary:

- To take appropriate measures for the social adaptation of women prisoners, which will help them to take the path of correction;

- To improve state support for single-parent, low-income families;

- To direct educational policy on education of underage girls of morality, decency, respect for the law; after all, children fall under negative influence much more often than adults;

- To improve, first of all, the working conditions of such categories of women as single mothers, mothers with children with disabilities, women who have minor children;

- To increase the competitiveness of women in the existing labor market;

- To provide state assistance to women's organizations and associations that really help women, etc.

The implementation of these actions will inspire faith in the future of women, and will create new priorities for their development and self-improvement. A woman should always understand that she was created not only for the birth and upbringing of children, but can influence the development of the state by her actions. ${ }^{19}$

General social prevention is implemented through state plans for economic and social development. Such plans are drawn up at both state and regional levels. ${ }^{20}$ It is no coincidence that the Ukrainian State Program for Combating Crime emphasizes that the severity of the criminogenic situation requires the implementation of largescale comprehensive measures by the state, of which priority should be given to legal support of law enforcement and improvement of crime prevention. ${ }^{21}$

We support the position that the work on the prevention of women's crime should cover all spheres of women's' life, which form their negative traits and often cause the intention to commit a crime. This is family, life, work. It is clear that a high level of professionalism of law enforcement agencies and public formations

19 T. V. Gapeka. Prospects for Combating Women's Crime in Ukraine. BULLETIN OF NTUU "KPI" 3. 2011. Pp. 195-199.

20 I. B. Meditsky, supra, note 4. Pg. 20.

21 Regulation of the Cabinet of Ministers of Ukraine "State Program to Combat Crime" / Decision № 3325-XII from June 25, 1993. Available at: https://zakon.rada.gov.ua/laws/ show/3325-12 
is necessary for the effectiveness of preventive measures, because the problem of women's crime is a painful issue for the whole Ukrainian society. ${ }^{22}$

Thus, the problems of preventing women's crime must be addressed in the fight against crime in general. It should be based on the state's economic development and political stabilization, on the introduction of special programs (State Program to Combat Women's Crime in Ukraine), on family support programs, and on the creation of special funds (Women's Aid Fund). Also, we are convinced that it is necessary to adopt the Law of Ukraine "On Crime Prevention".

Development and implementation of regional programs to prevent crime involve many actors, primarily public authorities and law enforcement agencies, NGos, religious denominations, youth organizations, public foundations, ethnic communities, other structures and individuals. ${ }^{23}$

The analysis of the current legislation, bylaws of law enforcement bodies of Ukraine and other documents gives grounds to single out the following main measures to prevent fraud committed by women in Ukraine:

- Prevention of economic crimes;

- Prevention of especially dangerous and serious crimes;

- Cessation of criminal activity of organized criminal groups, as well as professional criminals;

- Prevention of juvenile delinquency;

- Prevention of recidivism;

- Prevention and cessation of violations of public order and public safety, mass riots;

- Fight against property crimes. ${ }^{24}$

There is currently no special law on crime prevention in Ukraine. A number of draft Laws on Crime Prevention have been developed today, but they are more like scientific and theoretical abstracts on prevention theory than effective regulations that can solve the problem of crime prevention in general. Therefore, in our opinion, it is necessary to develop and adopt an appropriate legal act on crime prevention,

22 T. V. Gapeka, supra, note 19. Pg. 198.

23 A. Nazim. The Essence, Structure and Main Elements of Complex Programs for the Prevention of Regional Crime. LVIV STATE UNIVERSITY OF INTERNAL AFFAIRS 2. 2016. Pg. 391-402.

24 V. G. Sevruk. Normative and Legal Bases of Counteraction by Law Enforcement Bodies of Ukraine to the Crimes Committed by the Organized Groups and the Criminal Organizations which are Formed on an Ethnic Basis. YOUNG SCIENTIST 4. 2017. Pp. 337342. 
and based on the latter, to adopt a special law that provides for preventive measures against fraud committed by women.

General preventive measures are: Legal, socio-economic, organizational and managerial, ideological, socio-psychological, medical, psychological and pedagogical, socio-cultural and technical. General preventive measures are comprehensive, defining areas and methods of combating crime. This is due to the fact that general social crime prevention is ensured primarily by the development of Ukraine as a legal country, a country where people are recognized as the highest social value.

\section{PECUliarities of MEASURES to PREVENT FRAUD COMMITTED BY WOMEN IN THE EU COUNTRIES AND THE UNITED STATES}

First of all, it is important to note that one of the most important ways to prevent fraud committed by women is victimology because one of the main features of this crime is that it is committed with the direct participation of the victim in the illegal acquisition of property by the offender ${ }^{25}$.

The concept of "victim" is interpreted in the broadest sense, regardless of the recognition of the person as such by the investigator, the court or the fact of the appearance in the case and the detention of the offender. Moreover, among the victims, the legislation of the United States and other countries, as well as international law, includes not only the victims themselves, but also their relatives and friends. ${ }^{26}$ In short, victimology is of interest to victims of crime in the broadest, factual sense and in the sense of this term, which makes it possible to detail the objects of study, classify and create a typological portrait of victims of various crimes. ${ }^{27}$

Significant attention is paid to victimological crime prevention measures in the EU and the United States, including at the highest state level. The model is based on methods of restoring broken social ties in order to maintain public order, thus reducing the vulnerability of dissocialized groups. This model is the most popular among government officials, including law enforcement. It fits into the social and legal models of local self-government, which are being developed by jurists, sociologists

25 A. Andrushko \&I. Nesterova. CRIME IN THE SPHERE OF TOURIST BUSINESS: CRIMINOLOGICAL CHARACTERISTICS AND PREVENTION. IVA. (2016). Pg. 143.

26 S. M. Kochoi. CRIMINAL LEGISLATION OF RUSSIA AND FOREIGN STATES ON ENCROACHMENTS ON PROPERTY. Prospekt. (2006). Pg. 198.

27 E. V. Chuprova. RESPONSIBILITY FOR ECONOMIC CRIMES UNDER THE CRIMINAL LAW OF ENGLAND. Volters Kluver. (2007). Pg. 208. 
and criminologists. Under such conditions, compensation for the damage caused by the crime should be considered one of the most important indicators of justice. ${ }^{28}$ Victimology measures to prevent crime are already active in developed foreign countries, where the law provides that law enforcement agencies, along with other functions, deliver advice to the public on personal and property security, as well as psychological and material assistance to victims of crime, and help in conflict situations. ${ }^{29}$

After all, applying preventive measures, police officers thus create the necessary conditions for strict compliance with the law, detection and cessation of various offenses, and prevent possible encroachments on public relations, which are protected by law. ${ }^{30}$

In general, victim prevention is a specific activity of social institutions aimed at identifying, eliminating or neutralizing the factors, circumstances, situations that shape victim behavior and determine the commission of crimes. It includes the identification of risk groups and specific individuals with a high degree of victimhood, in order to restore or enhance their protective properties, as well as the development or improvement of existing special means of protection of citizens and individuals from crime. ${ }^{31}$

In criminal victimology, there are two main areas: The so-called academic area, which focuses on the analysis of theoretical aspects of modern victimology, and the -applied area, which develops the problems of increasing the effectiveness of existing legislation on protection of victims and abuse of power, effectiveness of domestic violence prevention programs, rape assistance programs, etc. ${ }^{32}$

In addition to discussing the problems of victim prevention at the international level, various methods of citizens' protection from criminal encroachment in a number of Western European countries and the United States are of practical interest. In general, the development of applied victimology in the EU and the United States is carried out in the following areas:

28 V. Kvashis \& L. Vavilova. FOREIGN LEGISLATION AND PRACTICE OF COMPENSATION FOR DAMAGE CAUSED TO THE HEALTH OF VICTIMS OF CRIME. LEGAL AND SOCIAL PROBLEMS OF PROTECTION OF VICTIMS OF CRIMES. (2007). Pg. 18-26.

29 S. Bielen \& P. Grajzl. Gender-Based Judicial Ingroup Bias in Sex Crime Sentencing: Evidence from Belgium. INTERNATIONAL JOURNAL OF LAW CRIME AND JUSTICE 62. 2020. https://doi.org/10.1016/j.ijlcj.2020.100394

30 E. M. Karpenko. Improvement of Strategic and Tactical Forms and Methods of Victimological Prevention of Crimes in Ukraine in the Modern Period. customs BUSINESS 5. 2015. Pg. 86-89.

31 Djuja Olexandr et al., supra, note 1. Pg. 311.

32 V. O. Tulyakov. VICTIMOLOGY (SOCIAL AND CRIMINOLOGICAL PROBLEMS). Legal Literature. (2000). Pg. 95-96. 
- Training of the person (development of algorithms of optimum behavior in criminogenic situations and special training);

- Increasing the level of protection of officials who perform functions related to the risk of criminal encroachment;

- Minimization of victimogenic situations;

- Protection and rehabilitation of victims of crimes.

The concept of victim prevention is based on the following: Informing the population about the current forms of crime and the possibility of effective crime prevention; ensuring the protection of potential victims; creating conditions for active cooperation between the population and the police. ${ }^{33}$

Also, it is important to note that in the EU and the United States there is quite strong state support for victimology programs. ${ }^{34}$ For example, in the United States, among the 72 programs with high rate of effectiveness, there is a project called "Adolescent Transitions Program", which is designed for adolescents aged 11-17 with delinquent behavior who use alcohol and drugs. The key to the success of this program is that its implementation involves not only psychologists and psychiatrists, but it also widely involves parents and family members of "difficult" adolescents, as well as their teachers.

"Big Brothers Big Sisters" is a very common program in the modern United States, the so-called public mentoring. The headquarters of this project is located in Philadelphia (Pennsylvania), has about 400 agencies across the country and serves more than 250 thousand children aged 6 to 18. The purpose of the program is to involve volunteers, i.e. mentors, to work with people of this age group who come from single, disadvantaged families, use alcohol and drugs, or whose family members are serving sentences for crimes. ${ }^{35}$

Another good example of the impact of crime with the participation of public associations is "Operation Peacekeeper", which was introduced in 1997 in Stockton (California) and whose experience is currently used in other United States cities. The program is designed for people aged 10-18 who are members of organized criminal groups or may be involved in the near future with high probability. ${ }^{36}$

33 O. Y. Yurchenko. Problems of Protection of Victims of Crimes in the European Countries and the USA. COMPARATIVE AND ANALYTICAL LAW 3. 2013. Pg. 335-338.

34 O. M. Knysh. Foreign Experience of Victimological Prevention of Violent Juvenile Delinquency. BULLETIN OF THE ACADEMY OF ADVOCACY OF UKRAINE 1. 2009. Pg. 102-107.

35 M. G. Kolodyazhny. MODERN FOREIGN EXPERIENCE OF PUBLIC INFLUENCE ON CRIME. LaW. (2017). Pg. 69.

36 M. G. Kolodyazhny, ibidem. Pg. 70. 
"Neighborhood Watch" is another fairly common type of program in the United States to provide information to the police about crimes committed. This practice began in the 1970s and then quickly spread to Canada, the United Kingdom and the Kingdom of the Netherlands. Thus, in the United States, about 20\% of families live in areas where such projects operate, and a third of them participate in these programs themselves. A key principle of neighborhood surveillance is to expand informal surveillance and timely inform the police about offenses. This leads to an increase in the number of arrests and, as a consequence, to a reduction in the level of local crime, especially its recurrence. This practice also helps to reduce the population's fear of crime and to increase the level of security in the area of residence. ${ }^{37}$

Programs often provide a system of measures of special criminological prevention, which belong to the field of criminal, procedural and penitentiary law. A characteristic feature in the fight against crime in the United States in recent decades is the desire for centralized planning and coordination of this area of activity, the creation of special bodies for this purpose and giving them fairly broad powers. ${ }^{38}$

Special anti-crime bodies in the United States that have performed, and some even continue to perform, their functions primarily through the implementation of appropriate prevention programs, in which the public is one of the main actors, include: the Advisory Correctional Board (1950); Committee on Youth and Juvenile Delinquency under the President of the United States (1961); Interdepartmental Council for the Coordination of National Programs for Combating Youth Crime (1968); National Alcohol Abuse Prevention Advisory Council (1970); National Commission on the Objectives and Standards of the Criminal Justice System and the Development of Long-Term Crime Prevention Programs (1971); National Center for Safety in Schools (1980), etc. ${ }^{39}$

Of particular importance in the context of this research are non-profit and public organizations. Public participation in crime prevention is one of the main victimological ideas. Here we deal with the case when the scientific idea is organically combined with the processes of institutionalization of the social movement, which arises spontaneously.

In Western Europe and the United States, an important and often the main element of the system of victim prevention of crime are public organizations established

37 D. Roe-Sepowitz \& K. Hickle. Comparing Boy and Girl Arsonists: Crisis, Family, and Crime Scene Characteristics. LEgAL AND CRIMINOLOGICAL PSYCHOLOGY 16. 2011. Pg. 277-288. http://doi.org/10.1348/135532510X505500

38 A. Voronin Yu. THE SYSTEM OF COMBATING CRIME IN THE UNITED STATES. Ural University. (1990). Pg. 132.

39 A. Voronin Yu, ibidem. Pg.78-81. 
to protect the interests of victims of crime, provide them with assistance and counteract recidivism. ${ }^{40}$

A retrospective analysis shows that social movements uniting victims of crime or those interested in assisting victims emerged more than 40 years ago in the United Kingdom and the United States, and served as a model for similar associations in other Western European countries. These organizations provided support to victims in at least three ways:

- Assistance in cooperation with the police during the investigation of the case, psychological support to the victims in the first days after the crime;

- Assistance at the court stage;

- Assistance in the form of financial or other forms of compensation, provision of premises for temporary residence.

In each case, representatives of organizations seek to assist in dealing with lawyers and, more importantly, are more in demand in dealing with insurance agencies.

Analyzing the experience of various victimological organizations, criminologists usually identify four positions:

- Organizational structure;

- Relations with other victimological organizations;

- The nature of the object of assistance;

- $\quad$ Priority areas of crimes for which work is carried out. ${ }^{41}$

After analyzing prevention programs, projects and special operations that have been carried out and continue to be implemented in various United States cities, we can come to the following conclusions:

a) They are aimed at preventing specific types of crimes or background phenomena of crime (mercenary, violent crime, alcoholism, drug addiction, etc.);

b) Designed for certain age groups of their participants - children (6-12 years), adolescents (14-18 years), young people (18-25 years), adults;

40 L. V. Tserkunyk. Foreign Experience in the Prevention of Recidivism. SCIENTIFIC BULLETIN OF UZHHOROD NATIONAL UNIVERSITY 49. 2018. Pg. 137-141.

41 R. T. Mawby \& M. L. Gill. CRIME VICTIMS: NEEDS, SERVICES, AND THE VOLUNTARY SECTOR. Routledge Kegan \& Paul. (1987). Pg. 14. 
c) Are implemented with the participation of various actors (police, volunteers, psychologists, teachers, parents, relatives, social workers, etc.);

d) Are based mainly on the provisions of a specific criminological precautionary theory (social control, social management, education, environmental design, etc. $)^{42}$

In many states, scientific centers at educational institutions are created, and researches of various indicators of victimization of the population are organized and carried out in special criminological institutions. ${ }^{43}$ It is assumed that prevention cannot be very effective if it is not organized on a systematic and coordinated basis and does not include measures to improve the lives of the population, improve criminal justice and the penitentiary system. ${ }^{44}$

If we consider the experience of the United Kingdom, the most commonly used preventive measures are to involve the population in cooperation with the police (patrolling, duty in the most criminogenic areas), in order to develop the victimological direction of the impact on crime. After all, this does not require large material costs, as these measures are carried out due to the inherent desire of everyone to self-defense. It is also interesting that the Government of the country has developed a program to help victims of crime. As for scientific activity, a lot of attention is paid to it - there are many articles and manuals, the content of which is self-defense against all kinds of criminal encroachments, including fraud.

In all educational institutions - from primary school to universities - classes in applied victimology are held. But the most important thing is that it is possible to undergo special training, and after mastering the information, it is also possible to develop skills of the most acceptable behavior in criminal situations, including the mechanism of fraudulent encroachment on the property interests of citizens. ${ }^{45}$

In general, crime prevention in the UK takes three main forms: situational, social, and community-based prevention. Specialists in the field of crime prevention, depending on what they see as the causes of crime, distinguish the following approaches to the prevention:

42 M. G. Kolodyazhny, supra, note 41. Pg. 78-79.

43 S. A. Butkevych. The Experience of the United States in Preventing and Combating Money Laundering. SCIENTIFIC NOTES OF THE TAURIDA NATIONAL UNIVERSITY NAMED AFTER V.I. VERNADSKY 21. 2008. Pg. 68-74.

44 A. V. Mykytchyk. Victimological Direction of Fraud Prevention: International Experience. BULLETIN OF THE ASSOCIATION OF CRIMINAL LAW OF UKRAINE 1. 2016. Pg. 378-386.

45 N. Revina \& A. Rostokinsky. Experience of Foreign Countries in the Development of Victimological Prevention of Fraud. BUSINESS IN LAW: ECONOMIC AND LEGAL JOURNAL 1. 2010. Pg. 182-185. 
- A structural approach that combines the implementation of effective crime prevention with significant socio-economic transformations in society;

- Psychological approach, which recognizes the crucial preventive importance of the impact on the identity of a potential offender, as well as persons who have already committed an offense (to prevent recidivism) 46 ;

- Situational approach, where the decisive role is given to the impact on social and physical factors of the environment, the combination of which creates a favorable situation for criminal acts. ${ }^{47}$

We can find in Germany quite an interesting experience of victim prevention of fraud. In schools, police officers have developed a special course on the basics of victimology, where police officers give lectures and conduct seminars on the application of the provisions of this area of work in their practice. Consultations with the population on various ways to protect citizens' property from fraud are used effectively and quite often. For the same purposes absolutely free of charge, and not only on radio and television there is advice on prevention of fraudulent encroachments on property interests of citizens. There is also a series of programs "Criminal Police Advises", with practical advice on preventing fraud. In many German states, along with government programs, there are many private programs to help victims of crime. They analyze in detail the changes in legislation and case law relating to security and social assistance to persons who have become victims of criminal encroachments, including fraudulent encroachments. ${ }^{48}$

It is also worth noting that the German Criminal Code distinguishes several types of fraud, in particular: Ordinary fraud (\$263), computer fraud (\$263a), fraud in obtaining subsidies (\$264), fraud in the investment sphere (\$264a), credit fraud (\$265a), payroll fraud (\$266a), insurance fraud (\$265), fraud involving the use of checks and credit cards (\$266b). Hundreds of crime prevention programs are currently being implemented in Germany, including those with the participation of law enforcement NGOs and individuals interested in the proper level of law and order, both at the level of individual lands, cities and at the national level.

From the variety of program-preventive influence on crime with the help of the public in Germany we can single out the project called "Jet", which was introduced

46 Pedro Pechorro et al. The Utility of Self-Reported Psychopathic traits in Predicting Recidivism among a Sample of Incarcerated Female Youths. INTERNATIONAL JOURNAL OF LAW AND PSYCHIATRY 71. (2020). https://doi.org/10.1016/j.ijlp.2020.101596

47 I. A. Konovalova. Experience in the Fight against Juvenile Delinquency in Europe and the USA. LAWYER 12. 2007. Pg. 59-69.

48 N. Revina \& A. Rostokinsky, supra, note 50. Pg. 14. 
in 2006 in Heilbronn (Baden-Württemberg) and is still being implemented. The essence of this program reflects its name, as it consists in the reactive, fast reaction of various subjects of preventive activity to violent crime in the juvenile environment of this city. In particular, the Heilbronn Police Department decided to change the local law enforcement concept to limit the exclusive response to juvenile violence already committed, while increasing the presence of police officers and volunteers in public places, especially on weekends and holidays. Out of 800 policemen of this city, law enforcement is also carried out by 90 volunteers, who perform their duties in civilian clothes and in case of illegal actions promptly inform the local police. ${ }^{49}$

The German Crime Prevention Institute (DFK) plays a key role in crime prevention in Germany at the current stage of crime, limiting its criminogenic potential in German society by strengthening citizens' sense of security and reducing harm from crime. DFK, together with federal, state and non-governmental agencies, develops a public strategy to prevent crime, and its focus is on cross-sectoral prevention activities. In addition, this entity combines numerous preventive initiatives, ensuring the implementation of criminological strategies, programs and activities at the national level. ${ }^{50}$ Also important is the informational and educational direction in the victimological prevention of fraud, as most victims of this crime were victimized precisely because of their own reckless or illegal behavior, which is often due to ignorance of victims and shortcomings of their legal education.

\section{CONCLUSIONS}

Prevention of women's crime, in particular women's fraud, is of strategic importance. The main measures to prevent fraud committed by women in Ukraine include the following groups of measures: Socio-economic (reducing the stratification of the population by property status, increasing wages); legal (improvement of normative-legal regulation, increase of legal education level of the population); organizational and managerial (improvement of fraud prevention committed by women in relation to regulatory, informational and material support, improvement of social control over such activities); ideological (formation of a moral position in members of society, focused on basic universal values, debunking criminal traditions, undermining the authority of leaders of the criminal environment); socio-psychological (formation of an atmosphere of public peace, confidence in their own safety and trust in law

49 M. G. Kolodyazhny, supra, note 40. Pg. 113.

50 G. G. Moshak. the USE of PRIVATE LAW IN CRIME PREVention. Crossroad. (2010). Pg. 90-92 
enforcement agencies); medical (disease prevention, treatment and resocialization of such persons).

An analysis of the experience of the EU countries and the United States in preventing female fraud allows us to conclude that it is useful to borrow some approaches. In particular, preventive work among the population and victimological prevention is relevant. Preventive work among the population requires the formation of an appropriate organizational infrastructure for the implementation of victimological measures. In our opinion, the most expedient way may be the creation of specialized organizations (public or private), which should carry out victimological "probing" of the criminological situation, as well as victimological prevention measures in a certain region, among certain groups or in a certain sphere of life.

Post-criminal victim prevention, which is carried out after a person has become a victim of a crime, should be important. Family assistance, including through special programs, is crucial for the prevention of women's crime. In addition to financial and material issues, families should receive significant assistance in caring for children, as well as emergency assistance in a crisis situation (for example, due to the illness of one of its members).

Particular attention should be paid to the "re-education" of women who have committed crimes and to the prevention of women's crime in penitentiary institutions. The penitentiary administration has a real opportunity to effectively influence the process of neutralization, blocking and elimination of determinants of crime in the country as a whole.

The basis should also be the economic development of the state and the political stabilization in it, the introduction of special programs (State Program for Combating Women's Crime in Ukraine), family support programs, and the creation of special funds (Women's Aid Fund). Given the significant role and influence of the church, especially in educating the morality of people, we assume that the work of the church in preventing crime in general and women' crime in particular can bear fruit. This is evidenced by world experience.

Juvenile law enforcement agencies have a significant role to play in preventing women's crime, as the educational effect on adolescent girls who may become criminals is not only a very humane, but also a very effective way of combating women's crime. In the prevention of crime in general and women's crime in particular, the same role can be played by public law enforcement organizations at the household level. Nowadays, such organizations are weakened, and in some places are even eliminated, which has caused considerable damage in the fight against crime. 
The experience of many countries shows the need to adopt a clear strategy to reduce fraud, which sets out policy objectives, measures and expected results. Strategies often include such goals as ensuring a high quality of life and provision of services, efficient spending. The availability and effective implementation of an anti-fraud strategy and monitoring of the effectiveness of social security programs can reduce fraud.

In the aspect of fraud prevention, work with the population should be aimed not only at directing a person's behavior in the legal direction (prevention of illegal behavior), but also at promoting morality, explaining the content of current law, clarification of the procedure for concluding civil law agreements, informing about their standard terms, liability for breach of the latter, ways to ensure the fulfillment of obligations, and promotion among citizens of statutory means of protection of their rights and interests (including judicial).

In this case, in order for moral and legal norms to become a regulator of human behavior, it is necessary to include their requirements in the system of real life relations of a particular individual, in order to acquire "personal meaning" for that individual. Theoretically, substantiated moral and legal provisions should be supported by facts from real life practice, close, clear and convincing examples for a person. By giving real examples when victims have suffered from fraud due to their illegal or immoral behavior, it is possible to convince people who are morally unstable to refrain from such actions.

In this case, information should not be general (abstract), but specific (on the example of real life situations), because a person usually perceives emotionally rich, concretized messages than neutral, psychologically uncolored, general information. For example, at railway stations, airports, markets and transport, loudspeakers should be used not only to warn of the existence of fraud, but also to provide information on examples of (perhaps typical) crimes actually committed there, indicating their characteristic features. Similarly, information campaigns should be built on television (targeted fraud prevention programs, victim advertising, etc.), in the print media, among electronic network users, mobile subscribers, and so on.

We should not underestimate the usefulness of specific advice in the form of memos, leaflets, manuals designed to prevent specific types of fraud (credit and financial, payment cards, electronic, trade, real estate, currency exchange, etc.), which could be distributed among the target groups of persons (employees of financial, commercial institutions, entrepreneurs, owners of valuable property, antiques, visitors to the stations, "visa seekers" in diplomatic missions, visitors to financial institutions, etc.). 
Finally, victimology prevention does not solve all problems, but together with the traditional prevention of crimes, it significantly increases the level of crime prevention, and makes prevention logically complete.

\section{REFERENCES}

A. Andrushko \& I. Nesterova. Crime in the Sphere of Tourist Business: Criminological Characteristics and PREVEnTION. IVA. (2016). Pg. 143.

A. F. Tokarev. General Warning In the Activities of LAW Enforcement Agencies. Academy of the Ministry of Internal Affairs of Russia. (1995). Pg. 8.

A. Nazim. The Essence, Structure and Main Elements of Complex Programs for the Prevention of Regional Crime. LVIV StATE University of INTERnAL AfFAIRS 2. 2016. Pg. 391-402.

A. V. Mykytchyk. Victimological Direction of Fraud Prevention: International Experience. BULLETIN OF the Association of CRiminal LaW of UkRaine 1. 2016. Pg. 378-386.

A. Voronin Yu. The System of Combating CRIme In the United States. Ural University. (1990). Pg. 132.

D. Roe-Sepowitz \& K. Hickle. Comparing Boy and Girl Arsonists: Crisis, Family, and Crime Scene Characteristics. Legal and Criminological Psychology 16. 2011. Pg. 277-288. http://doi. org/10.1348/135532510X505500

Djuja Olexandr et al. CRImınology. Atica. (2009). Pg. 242.

Djuja Olexandr et al. Prevention of CRimes. Atica. (2011).

E. I. Kairzhanov. The Concept, Structure And Types of Crime Prevention. HSh. MIA USSR. (1986). Pg. 52.

E. M. Karpenko. Improvement of Strategic and Tactical Forms and Methods of Victimological Prevention of Crimes in Ukraine in the Modern Period. Customs BusInESS 5. 2015. Pg. 86-89.

E. V. Chuprova. Responsibility fOR ECONOMIC CRIMES UndeR THE CRIMINAL LAW OF ENGLAND. Volters Kluver. (2007). Pg. 208.

G. G. Moshak. The Use of Private Law in Crime Prevention. Crossroad. (2010). Pg. 90-92 
22 Features of measures to prevent fraud committed by women: The experience of Ukraine, the European Union countries and the United States

Golina Volodymyr et al. Criminology: General And SpeCiAl PARTS. Kharkiv Law Institute. (2009). Pg. 53.

I. A. Konovalova. Experience in the Fight against Juvenile Delinquency in Europe and the USA. LAWYER 12. 2007. Pg. 59-69.

I. B. Meditsky. Prevention OF CRIME. Viktor Dyakiv. (2008). Pg. 27.

K. L. Popov. Victim of Fraud: Victimological Research. Kyiv. (2007). Pg. 17.

Marcela Pilar Aedo Rivera \& Patricia Varela Pino. Reflections about Gender Differences in Girls' Delinquency Behaviors in Chile. ONATI SOcIO-LegaL SERIES 1. (2020). Pg. 218-242. Available at: https://doi.org/10.35295/OSLS.IISL/0000-0000-0000-1164

M. G. Kolodyazhny. Violent EXtortion of Property in Ukraine: Criminological Characteristics, Determination and Prevention. Crossroad. (2010). Pg. 163.

M. G. Kolodyazhny. Modern Foreign Experience of Public Influence on CRime. Law. (2017). Pg. 69.

M. Lototsky. Features of Women's Crime Prevention. University SCIEntific Notes: Journal of

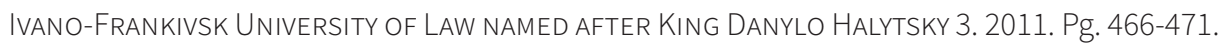

N. A. Chikisheva. Women's Fraud: Criminological and Victimological Characteristics. Vladivostok. (2011). Pg. 183.

N. Revina \& A. Rostokinsky. Experience of Foreign Countries in the Development of Victimological Prevention of Fraud. Business In LAW: EConomiC AND Legal Journal 1. 2010. Pg. 182-185.

L. V. Tserkunyk. Foreign Experience in the Prevention of Recidivism. SCIENTIFIC BULletin of UZHHOROD NATIONAL UNIVERSITY 49. 2018. Pg. 137-141.

O. M. Litvinov. General Social Vector in the Mechanism of Crime Prevention and Factors that Determine it. Bulletin of Kharkiv National University of InTERnal AfFAiRS 41. 2008. Pg. 111-117.

O. M. Podilchak. Motives and Motivation of CRimes Committed by Women. Ranok Publishing House. (2005). Pg. 16.

O. Y. Yurchenko. Problems of Protection of Victims of Crimes in the European Countries and the USA. Comparative And Analytical LaW 3. 2013. Pg. 335-338. 
O. M. Knysh. Foreign Experience of Victimological Prevention of Violent Juvenile Delinquency. BULletin of THE ACAdemy of AdVocacy of UkRaine 1. 2009. Pg. 102-107.

Pedro Pechorro et al. The Utility of Self-Reported Psychopathic traits in Predicting Recidivism among a Sample of Incarcerated Female Youths. INTERNATIONAL JOURNAL OF LAW AND PSYCHIATRY 71. (2020). https://doi.org/10.1016/j.ijlp.2020.101596

R. T. Mawby \& M. L. Gill. Crime Victims: Needs, Services, And the Voluntary Sector. Routledge Kegan \& Paul. (1987). Pg. 14.

S. M. Kochoi. Criminal Legislation of Russia and Foreign States on Encroachments on PROPERTY. Prospekt. (2006). Pg. 198.

S. Bielen \& P. Grajzl. Gender-Based Judicial Ingroup Bias in Sex Crime Sentencing: Evidence from Belgium. International Journal of LAW CRIme and JustiCe 62. 2020. https://doi.org/10.1016/j.ijlcj.2020.100394

S. I. Minchenko. The Main Directions of General Social Crime Prevention in Ukraine. ScIENTIFIC Bulletin of Kyiv National University of InTERnAl AfFairs 5. 2009. Pg. 102-110.

S. A. Butkevych. The Experience of the United States in Preventing and Combating Money Laundering. Scientific Notes of the TAurida National University Named after V.I. VERNADSKY 21. 2008. Pg. 68-74.

V. O. Tulyakov. Victimology (Social And CRiminological Problems). Legal Literature. (2000). Pg. 95-96.

V. G. Sevruk. Normative and Legal Bases of Counteraction by Law Enforcement Bodies of Ukraine to the Crimes Committed by the Organized Groups and the Criminal Organizations which are Formed on an Ethnic Basis. Young SCIENTIST 4. 2017. Pp. 337-342.

V. Kovalenko. General Social Conditions for Crime Prevention in the Economic Sphere. LAW OF UKRAINE 8. 2004. Pg. 12-18.

V. Kvashis \& L. Vavilova. Foreign LegisLation and PRACtice of Compensation for Damage CAUSED to the Health of Victims of Crime. Legal and Social Problems of Protection of Victims OF CRIMES. (2007). Pg. 18-26.

T. V. Gapeka. Prospects for Combating Women's Crime in Ukraine. BULLETIN OF NTUU “KPI” 3. 2011. Pp. 195-199. 